\title{
„Už nechceme chodit do školy společně s romskými dětmi“: segregace v obci a slovenském vzdělávacím systému
}

\author{
Radek Vorlíček \\ Katedra Obecné antropologie, Fakulta humanitních studií, Univerzita Karlova v Praze, U Kř́že 8, 15800 Praha 5
}

Do redakce doručeno 20. února 2017; k publikaci přijato 20. června 2017

\section{“WE DON'T WANT TO GO TO THE SAME SCHOOL WITH ROMA CHILDREN ANYMORE”: SEGREGATION IN THE VILLAGE AND THE SLOVAK SCHOOL SYSTEM}

\begin{abstract}
The aim of this article is to explore the dynamics of social marginality and dominance in one locality in western part of the Slovak Republic. Special attention is paid to interethnic coexistence and identity construction process. The article especially sheds light on many aspects of identity development in school and non-school settings and demonstrates how the process of boundary constructions is influenced by a range of political activities of community councils. The text is based on long-term, qualitative inductive and ethnographic fieldwork. The research is set within a larger social scale topic of research of integration and segregation tendencies in the Slovak school system.
\end{abstract}

KEY WORDS segregation; identity; ethnicity; Roma pupil; schools system; ethical aspects

ABSTRAKT Cílem článku je blíže prozkoumat sociální dynamiku marginality a dominance v obci, která se nachází v západním Slovensku. Speciální pozornost je věnována vybraným aspektům mezietnického soužití a procesu konstruování identity. Př́ispěvek objasňuje některé aspekty rozvoje identity ve školním i mimoškolním prostředí a ukazuje, jak zastupitelé obce svým jednáním ovlivňují proces konstruovaní hranic mezi Romy a Neromy. Předkládaný text je založen na kvalitativním, induktivním a etnografickém výzkumu. Makrosociálním rámcem výzkumu jsou témata fungování slovenského školství, zejména jeho integrační a segregační tendence.

KLÍČOVÁ SLOVA segregace; identita; etnicita; romský žák; školský vzdělávací systém; etické aspekty

\section{ÚVOD}

V předkládané studii se zabývám sociální dynamikou marginality a dominance v oblasti slovenského vzdělávacího systému. Zaměřuji se na vybrané aspekty mezietnického soužití a na proces konstruování identity v obci a základní škole. Pojednávám přitom zejména o klíčových aktérech a faktorech, které významným způsobem utvárí sociální prostor a formují interetnické vztahy. Speciální pozornost věnuji starostovi obce, který do velké míry etnizuje sociální vztahy a svým jednáním napomáhá polarizovat společnost na Romy a Neromy. Makrosociálním rámcem výzkumu jsou témata fungování slovenského školství, zejména jeho integrační a segregační tendence. Teoretickými inspiracemi této kapitoly jsou úvahy formulované Norbertem Eliasem a jeho žákem Johnem Scotsonem (1994) na jedné straně a myšlenky Eugeena Roosense (1989) a Pierra Bourdieua (1998) na straně druhé.

Studie je jedním $\mathrm{z}$ dílčích výsledků dlouhodobého a širšího výzkumného projektu, který byl realizován $\mathrm{v}$ rámci disertační práce (blíže Vorlíček 2016; 2017a; 2017b). Disertační práce se zabývá sociální dynamikou a interetnickými vztahy ve školním prostředí. V rámci doktorského studia jsem realizoval desetiměsíční výzkum ve dvanácti základních školách $\mathrm{v}$ různých českých a slovenských regionech (šest škol se nacházelo v České republice a šest na Slovenku). Z teoreticko-metodologického hlediska byl výzkum ukotven v antropologii vzdělávání (např. Spindler 2000, 1963, 1974; Hymes 1980; Mead 1972; Levinson - Pollock 2011) a založen na pomezí komparativní 
studie a výzkumné strategie „Multi-Sited Ethnography“, která byla rozpracována Georgem Marcusem v 90. letech 20. století (Marcus 1995, 1998). ${ }^{1}$ Výzkum byl kvalitativního typu. Primárnè se opíral o metodu pozorování, „the mainstay of the ethnographic enterpise“ (Werner, Schoepfle 1987, 257), která byla částečně doplněna o polostrukturované a nestrukturované rozhovory zejména s pedagogy a dalšími informátory z terénu (zastupitelé obcí, pracovníci neziskových organizací, zaměstnanci pedagogicko-psychologických center, obyvatelé lokality výzkumu apod.).

Dřive než se dostanu $\mathrm{k}$ jádru celého textu, udělám ještě malou významnou vsuvku $\mathrm{k}$ etickým aspektům výzkumu. Během práce $\mathrm{v}$ terénu jsem se maximálně snažil dodržovat standardy ochrany osobnosti těch, s nimiž jsem $\mathrm{v}$ terénu spolupracoval (informovanost, anonymita, zodpovědnost, otevřenost, upřímnost, poctivost, důvěryhodnost získaných informací, ochrana důvěrné komunikace, dodržení závazků, nezneužití výsledků). Název školy a lokality je přejmenován. Identita dětí i učitelů byla chráněna během výzkumu i po jeho skončení. $Z$ důvodu zvýšené ochrany identity školy otevřeně nepřiznávám všechna specifika školy i lokality a dokonce některé (méně podstatné) detaily záměrně pozměňuji natolik, aby školu a lokalitu téměř nebylo možné odhalit.

Etické principy jsou jasně a srozumitelně formulované (viz Etický kodex České asociace pro sociální antropologii), přesto $\mathrm{v}$ praxi jsou v mnoha ohledech téměř nereálné. Např́klad žákům ve školních třídách jsem byl po dohodě s ředitelem a trrídním učitelem představen jako student, zabývající se školským systémem. Nejednalo se o žádnou lež. S podrobným účelem mého výzkumu však žáci seznámeni nebyli, protože jsem se obával, že bych si tím poškodil svůj terén. Je tento př́stup v souladu s etikou výzkumu?² Část výzkumníků by zastávala názor, že takový přístup není v rozporu s etikou. Část by poukazovala, že to je na její hranici. Otázkou zůstává, kde leží taková hranice etického a neetického jednání? Tato pomyslná čára je možná definovatelná na papíre, ale ve skutečném terénu je mlhavější. Jak tvrdí Hammersley a Atkinson (2007, 221), to, co je a není přiměřené, závisí hlavně na kontextu. Jejich názor je mi blízký. Proto jsem se ve svém výzkumu řídil spíše vlastní sensibilitou, než abych se pevně a úzkostlivě držel apriorně formulovaných etických principů. „While codes of ethics provide useful guidelines, in the field ethical research relationships must be actively, if not creatively, negotiated, maintained, and adapted to the specifics of the situation or context" (Sluka 2012, 304).

\footnotetext{
1 Výzkumná strategie je uceleně a kriticky rozebrána $\mathrm{v}$ knize „Multi-Sited Ethnography“ (Falzon 2009), kde řada odborníků $\mathrm{z}$ antropologie, sociologie, geografie či migračních studií prezentuje její teoretické a praktické aspekty v kontextu současných rozmanitých výzkumů.

2 Do jaké míry může antropolog prozradit své téma, aby si tím neuzavřel terén? Do jaké míry to, jak se v terénu představíme (jak popíšeme, čím se zabýváme), může ovlivnit povahu poznatků, k nimž později v terénu dospějeme?
}

\section{OBEC LÍPOVÁ A ZÁKLADNÍ ŠKOLA ŠTEFANA ZÁVODNÍKA}

Terénní výzkum probíhal v obci Lípová poblíž města Jalovec v západní části Slovenské republiky. ${ }^{3} \mathrm{~V}$ obci žije přibližně 2300 obyvatel. $Z$ toho přibližně 400 dětí ve věku do 14 let a 150 mladistvých ve věku od 15 do 19 let. Podle oficiálních údajů je drtivá většina obyvatel slovenské národnosti. Pouze třináct lidí se hlásí $\mathrm{k}$ jiné národnosti (devět $\mathrm{k}$ mad’arské a čtyři k romské). V obci Lípová se nachází nelegální romská osada zvaná Daválie, která vznikla již před 150 lety a bývá místními obyvateli obce Lípová označována jako zdroj konfliktů. Podle zastupitelstva obce v osadě žije přibližně 500 až 600 romských obyvatel (jedná se jen o hrubý odhad, protože osada se neustále rozrůstá a počet obyvatel se postupně zvyšuje).

V rámci svého výzkumu jsem se primárně soustředil na školní prostředí. Realizoval jsem výzkum v Základní škole Štefana Závodníka. $\mathrm{V}$ průběhu deseti let se významně změnila sociální struktura této školy. V minulosti ji navštěvovalo 300 žáků, romských i neromských. Postupem času se ale škola proměnila v tzv. „romskou školu“. Ve školním roce 2014/2015 ji navštěvuje 125 romských žáků, z nichž 60 procent se nachází v hmotné nouzi. Ve škole vyučuje třináct kvalifikovaných pedagogů, jeden vychovatel, jeden asistent učitele, čtyři nekvalifikovaní asistenti z romské osady a jedna koordinátorka volnočasových aktivit. Škola má devět základních tříd a jednu speciální třídu pro žáky s mentálním postižením.

\section{SEGREGOVANÉ ŠKOLSTVÍ V OBCI LÍPOVÁ}

Zaměstnanci pošty odmítají nosit dopisy do romské osady. Místo nich poštu lidem $\mathrm{z}$ osady předávají pracovníci místní neziskové organizace. Jedná se o jednu $\mathrm{z}$ mnoha situací, která vypovídá o tom, že se v obci Lípová setkáte s velkou segregací a s téměř všudypř́tomnou protiromskou náladou, jež posiluje hranice mezi Romy a Neromy. Sociální konflikt v obci se postupně proměňuje v konflikt etnický. Téma chudoby a mizivé nabídky pracovních př́ležitostí je přerámováváno do dimenze etnické. Svoji roli v tomto procesu hrají obzvláště političtí zastupitelé obce. Zejména starosta používá $\mathrm{v}$ nepřiměřené míre etnické pojmy a kategorie $\mathrm{v}$ mnoha situacích, kde by o nich mluvit vůbec nemusel. Např́klad implicitně dává najevo, že romské děti netvoří mládež obce. Z jeho vyjádření vyplývá, že mládež obce je kategorie, do níž spadají pouze neromští žáci. Značně viditelná sociální a prostorová segregace mezi romským a neromským obyvatelstvem se projevuje ve všech sférách společenského života $\mathrm{v}$ obci včetně školského vzdělávacího systému. ${ }^{4}$ Základní školu Štefana Závodníka navštěvují

3 Z etických důvodů jsou názvy fiktivní.

4 Segregační strategie a mechanismy v souvislosti s Romy popisuje Skupnik (2007). Prostorové aspekty chudoby a sociálního vyloučení Džambazovič (2007). Segregační tendence na příkladu čtyř základních škol studie od společnosti Varianty a Člověk v tísni (2011). Teoretickou stránku segregace vysvětluje např́klad Burjanek (1997). 


\section{LÍPOVEC}

Štvrt'ročník pre obyvatelov obce Lípová
MAREC

2015

Číslo 1, ročník 8

\section{Podarí sa udržat’ mládež v obci?}

\section{Mesto Jalovec organizuje celomestské športové hry základných škôl. V prestávke športového zápasu sa zhovárajú dvaja chlapci, každý z iného družstva. „Dal si pekný gól.“ „Však aj ty hráš dobre, odkial’ si?““ „Ja som z Lípové, a ty?““ „To je super, ved’ aj ja som z Lípové.“}

$\mathrm{Aj}$ toto je jeden $\mathrm{z}$ dôsledkov stavu, ktorý nastal $\mathrm{v}$ obci v priebehu niekol'kých rokov. Základná škola, ktorej zriad'ovatel'om je obec, sa postupným odchodom žiakov do iných škôl v okolí stala zariadením, ktoré navštevujú len žiaci z rómskej komunity. Nevyhovuje to pritom ani obci, ani rodičom samotným.

V dedine dnes chýba mládež, ktorá by sa vzájomne poznala a združovala. Deti chodia do základných škôl v Jalovci, kde majú svojich kamarátov. Navštevujú tam školské kluby, krúžky, vystupujú při rôznych príležitostiach. S rovesníkmi z vlastnej obce sa stretávajú len náhodne. Zo základných odchádzajú na stredné školy, zase mimo obce.

Poznajú via históriu a kultúru okolitých obcí, ako tej svojej. Nemajú k nej zadný vzt'ah, nevytvárajú preto záujmové zoskupenia a spolky. Ked' obec organizuje akciu pre mládež, zväčša nemá jej podporu. Táto situácia nepriaznivo ovplyvňuje spoločenský život v Lípové. (...)

Otvorenie súkromnej školy je v záujme celej obce. Prajú si ho aj mladé rodiny, čo sa tu rozhodli usadit', či starí rodičia, ktorí by tak mali svoje vnúčata nablízku. Tí to však momentálne nijako ovplyvnit' nevedia. V rukách to majú rodičia budúcich prvákov a druhákov. Váhanie a vyčkávacia taktika dnes už nie sú namieste. Podarí sa udržat' mládež v Lípové?

Zpravodaj Lípovec, vydávaný jednou měsíčně místním obecním úřadem

Obr. 1. Zpravodaj Lípovec. V uvedeném článku z radničního zpravodaje se také píše: „V dedine dnes chýba mládež, ktorá by sa vzájomne poznala a združovala.“ Nová Soukromá Základní škola Andreje Ludovíta Radlinského se má stát tím místem, kde se mládež bude sdružovat a poznávat. Otázkou zủstává, zda otevření soukromé školy přinese kýžený efekt, o kterém se hovoří ve zpravodaji. Nebylo by lepší, aby se všichni žáci z obce vzdělávali, poznávali a sdružovali v jedné základní škole? Zlepší se v budoucnosti sociální situace v obci a okolí, když odmala učíme žít děti odděleně?

pouze Romové. Neromské děti dojíždí do základních škol do sousedních lokalit (zejména do Jalovce). Část neromských rodičů si přála, aby jejich děti mohly navštěvovat základní školu v obci. Nikoliv však školu, kterou by navštěvovaly společně s Romy, ale základní školu bez Romů. Za tímto účelem se obrátili na samosprávu obce Lípové s požadavkem zř́idit v obci druhou základní školu. Starosta vyšel iniciativě vstrríc a otevřeně podporuje vznik nové soukromé Základní školy Andreje Ludovíta Radlinského. ${ }^{5}$ Kromě tiché podpory starosta nabádá i zcela otevřeně své spoluobčany, aby své děti přihlásili do nově vznikající soukromé základní školy, a to prostřednictvím radničního zpravodaje „Lípovec“. Vznik nové soukromé základní školy spojuje s odpovědí na otázku, zda se podaří udržet mládež v obci (viz obr. 1).

5 Název této školy je taktéž fiktivní. 


\section{Súkromná základná škola v našej obci skutočnost’ou}

$\mathrm{V}$ posledných rokoch sa jednou $\mathrm{z}$ najpálčivejších tém $\mathrm{v}$ našej obci stalo vzdelávanie sa našich detí. Zo známych dôvodov museli rodičia už tých najmenších školákov zapisovat' na povinnú školskú dochádzku do základných škôl mimo našej obce.

S tým samozrejme súvisia vel'ké problémy s dopravou detí, ako aj d'alšie t’ažkosti so zabezpečením základného vzdelávania a mimoškolských aktivít, ktoré sú spojené s nemalými výdavkami z rodinných rozpočtov. Preto sa v minulom roku na základe petície rodičov budúcich prvákov obecné zastupitel'stvo uznieslo obrátit' sa na riaditel’a súkromných stredných škôl v našej obci s požiadavkou na zriadenie súkromnej základnej školy. Po stretnutí rodičov s riaditel’om Mgr. Janem Novákem bol z jeho strany daný prísl’ub na podanie žiadosti na Ministerstvo školstva SR na zriadenie súkromnej základnej školy v našej obci. Po prvom rokovaní na ministerstve sme nemali príliš vel'kú nádej, že žiadost' bude schválená. Napriek tomu sme sa nevzdávali a po mnohých d'alších rokovaniach a písomných zdôvodňovaniach sme boli úspešní. Dňa 22. 10. 2014 sme obdŕžali rozhodnutie z MŠ o zaradení Súkromnej základnej školy v obci Lípová, do siete základných škôl od 1.septembra 2015.

Zriad'ovatel'om je Mgr. Jan Novák a od budúceho šk. roku bude otvorený 1. aj 2. ročník. To znamená, že aj terajší žiaci prvého ročníka môžu od budúceho roku pokračovat' vo vzdelávaní v tejto škole. Zápis do 1.ročníka bude 7.februára 2015.

Verím, že rodičia terajších aj budúcich prvákov ocenia skutočnost', že po niekol'kých rokoch sa ich deti môžu vzdelávat’ v obci kde žijú spolu s kamarátmi, s ktorými chodili do materskej školy.

Obr. 2. Vznik soukromé základní školy v obci Lípová.

Starosta předal iniciátorům vzniku nové soukromé základní školy seznamy rodičů, kteří v blízké době budou řešit zápis svých dětí do základní školy. Zprostředkoval také jednání s ředitelem místní střední soukromé školy s cílem angažovat jej i pro vznik nové soukromé základní školy na území obce. Ministerstvo školství Slovenské republiky odsouhlasilo vznik nové školy v obci v roce 2014. První dvě tř́idy se otevřely 1. zárí 2015. Poplatek byl stanoven na padesát eur na žáka za měsíc. Vedení obce Lípová informovalo své občany o vzniku soukromé Základní školy Andreje Ludovíta Radlinského na informačním portálu obce (viz obr. 2). ${ }^{6}$

Nabízí se otázka, zdali by teoreticky romské děti mohly navštěvovat tuto soukromou základní školu. Odpověd' zní: Nemohly. Ekonomická situace jim to nedovoluje a kromě toho starosta Lípové tuto záležitost komentuje takto: „Súkromná škola má tú výhodu, že si môže dovolit aj vyberat žiakov podla určitých kritérií" (starosta Lípové, 10. 3. 2015).

V obci Lípová se základní školy etnicky homogenizovaly.

6 Z etických důvodů byla pochopitelně změněna identita ředitele soukromé základní školy a anonymizován byl i informační portál obce.
Vzniklo segregované školství: Základní škola Štefana Závodníka určená pro Romy a nová Soukromá Základní škola Andreje Ludovíta Radlinského určená pro neromské žáky. Školský vzdělávací systém v obci Lípová se stává selektivním systémem, který rozřazuje žáky do škol určených pro majoritu a minoritu. ${ }^{\text {? }}$

\section{KATEGORIZACE V OSADĚ A ŠKOLE}

\begin{abstract}
"One group can effectively stigmatize another only as long as it is well established in positions of power from which the stigmatized group is excluded"

(Elias 1994, xx).
\end{abstract}

Německý sociolog Norbert Elias, známý svoji knihou $O$ procesu civilizace (Elias 2006, 2007), jež je Mezinárodní sociologickou asociací označována za sedmou nejdůležitější sociolo-

7 Pro srovnání lze zmínit výzkum Daniela Hůleho, který mapuje, jak se segregace projevuje ve vztazích mezi čtyřmi základními školami v České republice (Viz Hůle 2011, 36-42). 
gickou práci dvacátého století, napsal také společně se svým žákem Johnem Scotsonem proslulou studii „The established and the outsiders" (Elias - Scotson 1994). V této knize Norbert Elias a John Scotson dopodrobna rozkrývají, jak se sociální nerovnost projevuje na mikrosociální úrovni. Zabývají se vztahem mezi sociálními skupinami v komunitě Winston Parva na předměstí Leicesteru. Ústředním tématem jejich studie je analýza moci, ideologie, stigmatizace, sociální struktury, hierarchie a sociálního vztahu mezi etablovanými a outsidery neboli starousedlíky a nově príchozími. ${ }^{8}$

Studie Norberta Eliase a Johna Scotsona je dodnes inspirativní po teoretické i praktické stránce. Díky ní jsem si během svého výzkumu v obci Lípová všímal jevů a situací, které by možná jinak unikaly mé pozornosti. Ve svém výzkumu jsem se sice primárně zaměřoval na školní prostředí, ale částečně jsem se také zajímal o interakci školního a mimoškolního prostředí. $\mathrm{Z}$ toho důvodu jsem zaznamenal, jak se obec Lípová rozmělňuje do několika sociálních skupin.

$\mathrm{V}$ průběhu terénního výzkumu jsem dospěl $\mathrm{k}$ názoru, že zatímco obyvatelé obce vnímají romskou osadu jako homogenní etnický celek, obyvatelé osady se za etnický a homogenní celek nepovažují a dělí se - na základě svých vlastních vyjádření - do několika skupin, které se ovšem částečně překrývají. ${ }^{9}$

1. starousedlíci

2. nově př́chozí

a) Romové z Jalovce $=$ „nepřizpůsobiví cikáni“

b) ostatní Romové z různých měst a obcí (nikoliv

z Jalovce)

3. bohatší Romové

Starousedlíci se považují za "pravé usedlíky“, kteři žijí v osadě řadu let a kteří tam mají své kořeny. Nově příchozí netvoří homogenní skupinu, ale víceméně se dále dělí do dvou skupin. První skupina se přestěhovala do osady z různých měst a obcí Slovenské republiky a budovala si své domy pouze $\mathrm{v}$ dolní ćásti osady. Postupem času se z nich stala jedna "větev“ (pojem převzatý od místních). Druhá se do osady přestěhovala z Jalovce a místními Romy je označována jako „nepřizpůsobiví cikáni“ (podle místních jsou to právě oni, kdo v obci Lípová dělá největši nepořádek a zakládá černé skládky). Romové v osadě se také částečně dělí podle výše ekonomického kapitálu. Většina $\mathrm{z}$ nich je chudých, ale někteř́ jsou extrémně chudí a žijí daleko pod hranicí chudoby. Naopak jedna ze skupin je vnímána jako „bohatší větev“. ${ }^{10}$

8 V českém prostředí na úvahy a myšlenky Norberta Eliase částečně navazuje Yasar Abu Ghosh, který v rámci svého dlouhodobého etnografického výzkumu ukazuje, jak se Romové na lokální úrovni rozmělňují na dvě frakce, jak se vypořádávají se sociální marginalizací, jaké mají strategie přežití a jak u nich probíhá konstrukce obrazu cikánství (viz Abu Ghosh 2008, 2010).

9 Eriksen (2012), parafrázující Epsteina (1978), uvádí, že „...čím větš́i je sociální distance daného člověka od skupiny, kterou klasifikuje, tím ménè podrobné výsledné etnické taxonomie bývaji“"(Eriksen 2012: 107).

10 Romové ani v České republice netvoří jednolité společenství. Dělí se do řady skupin a skupiny dále do podskupin a rodů. V České
V obci Lípová dochází k úzké interakci mezi romskou osadou Daválie a Základní školou Štefana Závodníka a dění ve škole je úzce propojeno s děním v romské osadě. Řada konfliktů se z osady přenáší do školy a naopak. Jedná se o častý jev, který musí ŕešit mnoho učitelů $\mathrm{z}$ pedagogického sboru. Jako př́iklad lze uvést jeden z mnoha záznamů, nacházející se v knize konfliktů (to je kniha, kam učitelé zapisují konflikty, které se odehrály v jejich tř́dě): „Sabastián sa nahlasoval na obed. Gabriel sa začal hádat so Sabastiánom. Franco bránil Sebastiána, vznikla medzi nimi bitka, Sabastián buchol Franca do nosa a tiekla mu krv z nosa. Po rozhovoru so žiakmi sme zistili, že konflikt vznikol ešte $\mathrm{v}$ osade aj medzi rodičmi a žiaci si následne doriesovali konflikt v škole" (záznam z knihy konfliktů, Základní škola Štefana Závodníka).

Další konflikt vznikl např́klad přijetím čtyř romských pracovníků na pozice romských asistentů. Obyvatelům osady nevadilo, že asistenti budou pomáhat dětem při studiu. Hlavním důvodem rozepře byla skutečnost, že všichni asistenti pocházeli pouze z jedné skupiny v romské osadě. Část obyvatelů osady to vnímala jako křivdu a nespravedlnost.

Rozdíly mezi skupinami v osadě jsou žáky vnímány i v prostorách školy a školní tríídy. $\mathrm{V}$ první třídě na Základní škole Štefana Závodníka tř́dní učitelka nemá zasedací pořádek a většinou si nechává žáky sedat podle jejich uvážení. Gender $\mathrm{v}$ této třídě hraje pouze okrajovou roli. Žáci a žákyně se o vyučovacích hodinách i o přestávkách nesdružují podle genderu tak, jak jsem to zaznamenal v jiných prvních třídách - např. v první tř́íd Základní školy Jana Kollára (viz Vorlíček 2016: 450-453). Sdružují se podle převzaté, sociálně konstruované meziskupinové identifikace.

"Vidíte támhle ten stưl? To jsou dèti $z$ jedné větve“ (učitelka první třídy, Základni škola Štefana Závodníka, 10. 3. 2015).

Je pozoruhodné, že žáci v první trrídě jsou ve velké míre schopni vnímat lokální a socioekonomickou diferenci a jí odpovídající sociální skupiny. Žáci z první třídy Základní školy Štefana Závodníka vnímají rozdíly v lokalitě a řídí se jimi při sociálních interakcích v základní škole. „Diference, určitá distinktivní vlastnost, bílá nebo černá barva kủže, štíhlost nebo tlouštka (...) se stává viditelnou, zřejmou, ne-indiferentní, společensky průkaznou diferencí jedině tehdy, je-li vnímána někým, kdo je schopný diferencovat - neboli kdo je rovněž zapojen do dotyčného prostoru, a proto není indiferentní a vládne kategoriemi vnímání, klasifikačními schématy, vkusem, jež mu diferencování a rozlišování (...) umožňujị (Bourdieu 1998, 17).

Základní škola ovšem v určitých situacích dětem vštípené skupinové linie odbourává a překračuje. $\mathrm{V}$ první trí́dě se to děje zejména $\mathrm{v}$ těch situacích, kdy třídní učitelka o vyučovací

republice žijí v současné době skupiny Romů Slovenských (Servika), Madarských (Ungrika), Olašských (Vlachika) a potomci původních tzv. českých a moravských Romů - k historii Romů v Č R a na Slovensku viz Nečas (2002), Hübschmannová (2002), Ríčan (2000) a Daniel (1994). 
hodině vytváří pracovní skupinky podle svého uvážení, bez ohledu na skupinovou prríslušnost. Tvorba skupin v jejím podání tedy není libovolná. Naopak je to záměrná socializační strategie třídní učitelky. Právě v těchto chvílích se totiž děti z celé osady lépe poznávají. Spolupracují a překračují lokální linie.

Třídní učitelka první třídy vytváři čtyři libovolné skupinky. Přiděluje jim jména podle ročního období: jaro (2 chlapci a 1 dívka), léto (2 chlapci a 1 dívka), podzim (2 dívky a 1 chlapec) a zima (2 chlapci a 2 dívky). Děti mají nakreslit cokoliv z ročního období. Například první skupina kreslí cestu do školy na jaře, čtvrtá kreslí to, co žáci potkávají v zimě cestou do školy, atd. Učitelka dětem slepila dvě velké čtvrtky dohromady. Každá skupina má za úkol společně namalovat jeden obrázek. Nejprve se však musí dohodnout, jak obrázek bude vypadat. Na konci druhé vyučovací hodiny bude každá skupinka mít vlastní divadelní scénu pred tabulí, při které odprezentuje a popíše výtvor svým spolužákům.

Učitelka směřuje dèti k tomu, aby závěrečný výtvor před tabulí neodř́kával jen jeden žák ze skupiny. Zároveň dètem zdürazňuje, že kdokoliv, kdo bude mluvit za skupinu, musí mluvit v prvním čísle množného čísla (tedy „my“).

Učitelka: „My všichni budeme mluvit o obrázku. My musíme spolu spolupracovat. My tvoříme skupinu." (při vysvětlování první osoby množného čísla učitelka obchází první skupinu, která se rozhodla predstavovat svi̊j projekt pred tabuli)

Děti ze skupiny zima tak začínají popisovat svůj projekt následovně: „My jsme nakreslili sníh a sněhuláka (...).“

Učitelka: „A proč jste nakreslili sníh a sněhuláka?"

Déti: „Protože je zima."

Učitelka: „A co dál?"

Děti: „V zimě se koulujeme.“

Učitelka: „A ještě od Simonky jsem nic neslyšela.“

Simonka: „My jsme nakreslili obláčky.“

(záznam z pozorování, první třída, Základní škola Štefana Závodníka, 10. 3. 2015)

Škola rovněž částečně homogenizuje žáky do jedné kategorie tím, že pomáhá budovat jednotnou romskou identitu - pořádá např. festival romské kultury. Ve vzdělávacím programu jsou silně zastoupeny „romské tance“ a žáci mají i o „romské kuchyni“. ${ }^{11}$

11 V České republice jedno $\mathrm{z}$ velice kontroverzních a diskutabilních doporučení „Analýzy faktorů bránících úspěšnému vstupu sociálně vyloučených osob do vzdělávacího systému“ (CEROP 2010, 83-85) zní následovně: „Je třeba jasně definovat kýžený cílový stav je-li tímto stavem úspěšná integrace Romů do české společnosti (...), tak je jakákoli podpora romských specifik (romské kultury, identity, jazyka ad.) faktorem, který tuto integraci výrazně ztěžuje, resp. ji patrně vůbec znemožňuje." Doporučení vlastně říká, že inkluze prostřednictvím podporování romských specifik je nutně odsouzena $\mathrm{k}$ neúspěchu, a tedy představuje jen jinou formu exkluze (úvahy studie pochopíme bliže, když zjistíme, že jedním z autorů studie je Marek Jakoubek, který je nechvalně proslulým kritikem romského etnoemancipačního procesu). S touto myšlenou lze polemizovat, protože
Existuje více perspektiv, které se v určitých situacích překrývají. Učitelé tvrdí: „jsme romská škola“, „toto jsou romské děti“. Sami žáci se občas s tvrzením učitelů identifikují. Často však zdůrazňují také identifikaci z osady. Myslím si, že děti $\mathrm{z}$ romské osady se postupně učí nejenom sdílet kolektivní identitu ve smyslu jediného „my“, ale i přecházet a přepínat mezi dalšími identifikacemi. ${ }^{12}$ „Each individual always belongs to several social units: a nation, a profession, a family, a political party, an ethnic group, a religion organization, and so on, and belongs to all of them at the same time. One is aware of belonging to these groups, networks, and categories, and is so recognized and identified by others, members and nonmembers, in term of this belonging. Generally, the individual prefers one or the other identity so that there is a hierarchy of identities for each person: one is first of all a Belgian, then a Fleming, a train conductor, a Catholic, and so forth. This hierarchy can be inverted or changed in time, or one social identity can simply be more relevant that others in a given context" (Roosens 1989, 16).

Identitární a kategorizační proces je specifický a v každém sociokulturním prostředí může probíhat trochu odlišně. $\mathrm{V}$ porovnání s ostatními navštívenými školami je vcelku zajímavé, že velká část učitelů této školy neupřednostňuje vizuální kategorizaci při označování Romů, ale řídí se spíš lokální příslušností k osadě: kdo v ní žije, toho učitelé dlouhodobě považují za Roma. Romství je tak závislé na bydlišti a Romem se stává i ten, kdo by teoreticky díky svému vzhledu mohl být považován za Neroma.

„Školu navštěvuje několik bílých dětí. Jsou to ale Romové. Žijí v osadě (koordinátorka volnočasových aktivit).

Bylo by zajímavé blíže prozkoumat vztah mezi sociální strukturou a vnímáním (fyzického) vzhledu. Změní se vnímání fyzického vzhledu u těch obyvatel, kteří se přestěhují $z$ obce do romské osady? Dochází v očích obyvatel i k tzv. „ztmavnutí “ u těch sociálních aktérů, kteří se posouvají ke spodnímu patru sociální stratifikace? Můžeme „bělost“ považovat za ideologii vázanou na sociální status? Za významnou a dodnes aktuální považuji také otázku, kterou si pokládá Richard Jenkins (1997, 39): „Jak rozlišujeme mezi lokálními, etnickými, regionálními a národními identitami?“" Myslím si, že výše uvedené otázky nejsou zatím definitivně objasněny a mohou být námětem pro další navazující výzkum.

Romové mají právo na svoji identitu i na podporu svého jazyka. Toto právo stanovuje Listina základních práv a svobod ČR, Rámcová úmluva o ochraně národnostních menšin, Evropská Charta regionálních či menšinových jazyků, Zákon č. 561/2004 Sb., o předškolním, základním, středním, vyšším odborném a jiném vzdělávání.

12 „Podle potřeb situace a sledovaných cílů může člověk volit mezi různými referenčními skupinami a zdůrazňovat tu či onu př́slušnost“ (Barša, Strmiska 1999, 83). 


\section{ZÁVĚR}

Přestože čelní představitelé slovenského vzdělávacího systému hovoří o konceptu rovnosti, ve skutečnosti se ukazuje, že v každodenní realitě a školní praxi má současný vzdělávací systém $\mathrm{k}$ rovnosti daleko a $\mathrm{v}$ některých obcích spíše nerovnosti podporuje, než aby je nějakým významným způsobem zmírňoval či odbourával.

Primárním zájmem výzkumu, který prezentuji v tomto člán$\mathrm{ku}$, bylo popsat a analyzovat slovenský vzdělávací systém, zejména jeho segregační tendence, a to $\mathrm{v}$ konkrétním kontextu zkoumané lokality. V tomto ohledu jsem dospěl k šesti hlavním bodům závěru, které se vážou nejen k tématu segregace, ale i procesu kategorizace:

1. Zastupitelé obce svým jednáním do velké míry znemožňují vzájemný dialog mezi občany a nadužíváním etnické kategorie a přerámováním problému chudoby do dimenze etnické nejenom zesilují vnímání etnických vazeb a identit, ale $\mathrm{v}$ konečném důsledku také polarizují společnost na Romy a Neromy (Romové v obci jsou definováni jako protiklad $\mathrm{k}$ majoritě). Je třeba říci, že zároveň tím ale také posilují dialog a soudržnost uvnitř těchto skupin („nepř́ítel“ sjednocuje).

2. Segregované základní školství v obci Lípová limituje romským žákům přístup mezi majoritu. Školský vzdělávací systém, který by za určitých podmínek mohl fungovat jako nástroj sociální mobility, se stává spíše nástrojem sociální exkluze, protože napomáhá udržovat Romy $\mathrm{v}$ podřadném postavení a zároveň výrazně přispívá $\mathrm{k}$ separaci uvnitř obce. V obci Lípová nalezneme školu pro Romy a školu pro Neromy. Podle Nekorjaka, Souralové a Vomastkové (2011: 677) jsou přitom romské školy odrazem sociálního postavení romských rodin i distance majority vůči této skupině, která je vidět jak na př́padě škol, tak na př́ípadě vyloučených lokalit.

3. Segregaci umožňuje soukromé vlastnictví - škola jen pro bílé je možná jen jako soukromá. Přitom bílí nebydlí jen jinde, ale taky si (někteří z nich) mohou dovolit školu zaplatit. Zde vstupuje do hry kapitalismus.

4. Na jednu stranu se sociální prostor v základní škole v mnoha ohledech podobá světu $\mathrm{z}$ romské osady (uzavřenost, chudoba, marginalizace, členění z osady apod.). Na druhou stranu ve škole pracují pedagogové, kteří aktivně vytváří jiná „my“ - viz př́klad o tvorbě skupin v první třídě.

5. Pedagogové Základní školy Štefana Závodníka nekategorizují a nedefinují romské žáky tolik podle fyzického vzhledu či barvy pleti jako spíš podle místa bydliště - romské osady.

6. Na základní školu bychom se měli dívat jako na hřiště identit. Myslím si, že s ohledem na dění v lokalitě romští žáci postupem času do jisté míry poznávají, že identita je mnohotvárná a fragmentovaná. ${ }^{13}$

13 Eriksen v knize o Frederiku Barthovi poukazuje, jak je v současné době nahližžno na identitu: „Identity now come to be seen as more plastic and malleable than before, as something flexible and shifting in an almost chameleon-like way" (Eriksen 2015, 105).

\section{LITERATURA}

Abu Ghosh, Yasar (2010): Crediting Recognition: Monetary Transactions of Poor Roma in Tercov. In: Michael Stewart - Márton Rövid (eds.): Multi-disciplinary Approaches to Romany Studies. Budapest: Central European University, 91-107.

Abu Ghosh, Yasar (2008): Escaping Gypsyness: work, power and identity in the marginalization of Roma. Disertační práce. Vedoucí práce: František Vrhel. Univerzita Karlova. Ústav etnologie.

Barša, Pavel - Strmiska, Maxmilián (1998): Národní stát a etnický konflikt: politologická perspektiva. Brno: Centrum pro studium demokracie a kultury.

Bourdieu, Pierre (1998): Teorie jednání. Raisons pratiques: sur la théorie de l'action. 1. vyd. Praha: Karolinum.

Burjanek, Aleš (1997): Segregace. Sociologický časopis, 33(4), 423-434.

CEROP (2010): Analýza faktorů bránících úspěšnému vstupu sociálně vyloučených osob do vzdělávacího systému [online]. Centrum aplikované antropologie a terénního výzkumu při Katedře antropologie FF ZČU (CAAT). Dostupné z: http://cerop.2142.net/133s [cit. 8. 1. 2015].

Daniel, Bartoloměj (1994): Dějiny Romů: vybrané kapitoly $z$ dějin Romů v západní Evropě, v Českých zemích a na Slovensku. Olomouc: Univerzita Palackého.

Džambazovič, Roman (2007): Priestorové aspekty chudoby a sociálneho vylúčenia. Sociológia - Slovak Sociological Review, 39(5), 432-458.

Elias, Norbert (1994): Introduction: A Theoretical Essay on Established and Otsider Relations. In: Elias, Norbert - Scotson, John L., eds., The established and the outsiders : a sociological enquiry into community problems. London: Sage Publications, xv-lii.

Elias, Norbert (2006): O procesu civilizace: sociogenetické a psychogenetické studie. 1. Proměny chování světských horních vrstev na Západě. Praha: Argo.

Elias, Norbert (2007): O procesu civilizace: sociogenetické a psychogenetické studie. 2. Promèny společnosti. Nástin teorie civilizace. Praha: Argo.

Elias, Norbert - Scotson, John L. (1994) The established and the outsiders: a sociological enquiry into community problems. London: Sage Publications.

Epstein, Arnold Leonard (1978): Ethos and Identity: Three Studies in Ethnicity. London: Tavistock Publications; Chicago: Aldine Pub. Co.

Eriksen, Thomas Hylland (2012): Etnicita a nacionalismus: antropologické perspektivy. Praha: Sociologické nakladatelství (SLON).

Eriksen, Thomas Hylland (2015): Fredrik Barth: An Intellectual Biografy. London: Pluto Press.

Falzon, Mark Anthony Ed. (2009): Multi-Sited Ethnography: Theory, Praxis and Locality in Contemporary Research. Ashgate.

Hammersley, Martyn - Atkinson, Paul (2007): Ethnography: Principles in practice. Third edition. Taylor \& Francis e-Library.

Hůle, Daniel (2011): Tendence Spádových škol v lokalitě. In: Varianty, Člověk v tísni, o. p. s.. Pojdte do školy! (Ne)Rovné šance na vzdělávání znevýhodněných dětí, 36-42. Dostupné z: http://www.ptac.cz/data/Pojdte_do_ skoly.pdf [cit. 2015-11-26].

Hübschmannová, Milena (2002): Šaj pes dovakeras. Můžeme se domluvit. Olomouc: Univerzita Palackého.

Hymes, Dell (1980): Language in education: ethnolinguistic essays. Washington, D. C.: Center for Applied Linguistics.

Jenkins, Richard (1997): Rethniking ethnicity: Arguments and Explorations. London, Thousand Oaks, New Dehli: SAGE ublications Ltd.

Levinson, Bradley A. - Pollock, Mica (2011): A companion to the anthropology of education. Chichester, West Sussex; Malden, MA: Wiley-Blackwell.

Marcus, George E. (1995): Ethnography in/of the World System: The Emergence of Multi-Sited Ethnography. Annual Review of Anthropology, 24, 95-117.

Marcus, George E. (1998): Ethnography through thick and thin. Princeton, N. J.: Princeton University Press.

Mead, Margaret (1972): Coming of age in Samoa: a psychological study of promitive youth for western civilisation. New York: Morrow Quill.

Nečas, Ctibor (2002): Romové v České republice včera a dnes. Olomouc: Univerzita Palackého v Olomouci.

Roosens, Eugeen E. (1989): Creating Ethnicity: The Process of Ethnogenesis. Newbury Park, Calif.: Sage Publications.

Říčan, Pavel (2000): S Romy žít budeme - jde o to jak: dějiny, současná situace, kořeny problémů, naděje společné budoucnosti. Praha: Portál. 
Skupnik, Jaroslav (2007): Světy se zrcadlem. Marginalizace a integrace z hlediska sociopsychologické dynamiky společnosti. Sociologický časopis / Czech Sociological Review, 43(1), 133-148.

Sluka, Jeffrey A. (2012): Introduction: Fieldwork Ethics. In: Robben, Antonius C. G. M. - Sluka, Jeffrey A. eds., Ethnographic fieldwork : an anthropological reader. 2nd ed., Malden, MA: Wiley-Blackwell.

Spindler, George Dearborn (1963): Education and culture: anthropological approaches. New York: Holt, Rinehart and Winston.

Spindler, George Dearborn (1974): Education and cultural process: toward an anthropology of education. New York: Holt, Rinehart and Winston.

Spindler, George Dearborn (2000). Fifty years of anthropology and education 1950-2000: a Spindler anthology. Mahwah, N. J., London: Lawrence Erlbaum Associates.

Varianty - Člověk v tísni, o. p. s. (2011): Pojdte do školy! (Ne)Rovné šance na vzděláváni znevýhodněných dětí. Praha. Dostupné z: http://www.ptac. cz/data/Pojdte_do_skoly.pdf [cit. 2015-11-26].

Vorlíček, Radek (2016): „Vy jste dole, my nahoře“: Sociální a etnické hranice v základní škole. Lidé města/Urban People, 18(3), 441-462.
Vorlíček, Radek (2017a): „Vyvolení, outsideři a Romové“: Selekce žáků v základní škole s výběrovými třídami. Slovenský národopis, 65(1), 26-38.

Vorlíček, Radek (2017b): „S odlišností se nekamarádíme“: sociální exkluze žáka se speciálními vzdělávacími potřebami. AntropoWebzin, 1-2/2017, 21-29. Werner, Oswald - Schoepfle, Gordon Mark (1987): Systematic Fieldwork. Vol. 1. Newbury Park: Foundations of ethnography and interviewing.

\section{AUTOR}

Radek Vorlíček - absolvent magisterských oborů Sociální antropologie a Specializace v pedagogice na Univerzitě Pardubice. V současné době student doktorského studijního programu Obecná antropologie - Integrální studium člověka na Fakultě humanitních studií Univerzity Karlovy v Praze. Mezi jeho odborné zájmy patř́ antropologie vzdělávání a antropologie dětství. Zabývá se výzkumem sociální inkluze a exkluze v základních školách, nízkoprahových klubech a sociálně vyloučených lokalitách. Kontakt: Vorlicek.r@gmail.com 